UDC 911.9

LBC 26.324

\title{
MODERN TECTONIC ACTIVITY OF ALEXANDROVSKY GRABEN (LOWER VOLGA) ON THE RE-LEVELLING DATA ${ }^{1}$
}

\author{
Denis A. Solodovnikov \\ Volgograd State University, Volgograd, Russian Federation \\ Natalya M. Khavanskaya \\ Volgograd State University, Volgograd, Russian Federation \\ Nikolay V. Vishnyakov \\ Volgograd State University, Volgograd, Russian Federation \\ Stanislav S. Shinkarenko \\ FSC of Agroecology RAS; Volgograd State University, Volgograd, Russian Federation
}

\begin{abstract}
The article presents the results of the current tectonic mobility analysis of the Alexandrovsky graben - widely known tectonic structure in the Lower Volga region. This graben is one of the strongest occurrence of fault tectonics on the Russian Plain. Like other dislocations, it is laid on the contact of two major tectonic elements of the East European platform - the Pachelmsko-Saratov aulacogen and the Caspian syneclise. When the Volgograd Hydroelectric Power Station (1950s) was designed, the faults systems of the Lower Volga region were $\sim$ studied in details to identify the presence of modern movements. During that period, passivity of faults was ascertained. In the middle of the 2000s, the authors identified geomorphological features of active modern tectonic movements in the Alexandrovsky graben area. In 2009, a reference geodetic network was laid to perform long-term $\checkmark$ monitoring and to determine the rates of tectonic movements and a primary levelling and elevation alignment of reference points were carried out. The depth and method of referent points laying exclude the influence of seasonal soil processes on the high-altitude position of the geodetic base points. Re-levelling was conducted in 2016-2017. The results of the double levelling match the III (third) class. The results of levelling allow us to estimate the average velocity of vertical displacement in $0,6-1,1 \mathrm{~mm} /$ year. Such speeds are almost limitless for platform sections of the earth's crust. In different parts of the graben, both upward and downward movements were detected. The obtained results indicate the presence of complex and multidirectional modern movements in a limited area of the Aleksandrovsky graben.

Key words: Modern tectonic movements, Alexandrovsky Graben, Lower Volga region, geodetic methods.

СОВРЕМЕННАЯ ТЕКТОНИЧЕСКАЯ АКТИВНОСТЬ АЛЕКСАНДРОВСКОГО ГРАБЕНА (НИЖНЕЕ ПОВОЛЖЬЕ) ПО ДАННЫМ ПОВТОРНОГО НИВЕЛИРОВАНИЯ ${ }^{1}$

\author{
Денис Анатольевич Солодовников \\ Волгоградский государственный университет, г. Волгоград, Российская Федерация \\ Наталья Михайловна Хаванская \\ Волгоградский государственный университет, г. Волгоград, Российская Федерация
}




\section{Николай Владимирович Вишняков}

Волгоградский государственный университет, г. Волгоград, Российская Федерация

\section{Станислав Сергеевич Шинкаренко}

Федеральный научный центр агроэкологии, комплексных мелиораций и защитного лесоразведения Российской академии наук, Волгоградский государственный университет, г. Волгоград, Российская Федерация

Аннотация. В статье излагаются результаты оценки современной тектонической подвижности широко известной в Нижнем Поволжье тектонической структуры - Александровского грабена. Указанный грабен является одним из наиболее ярко выраженных проявлений разрывной тектоники на Русской равнине. Подобно другим дислокациям, он заложен на контакте двух крупных тектонических элементов Восточно-Европейской платформы - Пачелмско-Саратовского авлакогена и Прикаспийской синеклизы. В период проектирования Волгоградской ГЭС (1950-е годы) системы разломов Нижнего Поволжья подробно исследовались на предмет наличия современных движений. В тот период была констатирована пассивность разломов. В середине 2000-х годов авторами выявлены геоморфологические признаки активных современных тектонических движений в районе Александровского грабена. В 2009 году там была заложена реперная геодезическая сеть для долговременного мониторинга и определения темпов тектонических движений и проведено первичное нивелирование и высотная увязка реперов. Глубина и способ закладки реперов исключают влияние сезонных почвенных процессов на высотное положение пунктов геодезической основы. Повторное нивелирование было проведено в 2016-2017 гг. Результаты двойного нивелирного хода соответствуют III классу. Результаты нивелирования позволяют оценить среднюю скорость вертикального смещения в 0,6-1,1 мм/год. Такие скорости практически предельны для платформенных участков земной коры. На разных участках грабена выявлены как восходящие, так и нисходящие движения. Полученные результаты указывают на наличие сложных и разнонаправленных современных движений на ограниченном участке Александровского грабена.

Ключевые слова: современные тектонические движения, Александровский грабен, Нижнее Поволжье, геодезические методы.

На протяжении последних десятилетий существенно изменились общие взгляды на природу внутриплатформенных деформаций, источники тектонических сил, механизмы деформаций земной коры и другие принципиальные проблемы тектоники и геодинамики платформ $[11,17,19]$. Принципиально важным является вопрос о закономерностях локализации зон избыточных напряжений и повышенной дислоцированности платформенных массивов, о выделении и спецификации зон повышенной геодинамической активности $[11,20]$. Детальное изучение современной подвижности локальных структур - необходимое условие для понимания процессов глобальной тектоники, в частности, для реконструкции кайнозойского поля напряжений востока Русской плиты и Урала и понимания процессов неотектоники этой области [6]. Кроме того, изучение современных тектонических движений имеет и практическое значение - геоэкологическое, в частности, связанное с оценкой рисков природно-техногенных катастроф [3, 18] , а также связанное с поиском полезных ископаемых [16].
Нижнее Поволжье - одна из интереснейших в плане геотектоники областей. В общем структурном плане юго-восток Русской платформы является наиболее сложно дислоцированной ее частью (за исключением окраин платформы) [5]. Здесь различаются как крупные тектонические образования - антеклизы и синеклизы, так и осложняющие их более мелкие структурные формы и тектонические элементы - мелкие сбросы, грабены, соляные купола [2].

В Нижнем Поволжье Русская платформа представлена двумя надпорядковыми структурами - Воронежской антеклизой и Прикаспийской синеклизой, разделенными между собой южной ветвью Пачелмско-Саратовского авлакогена. Обе структуры имеют очень древний возраст заложения. На северо-западной окраине Прикаспийской синеклизы значительное развитие имеют осадочные образования верхнепротерозойского возраста. Вообще, весь осадочный комплекс характеризуется здесь исключительной полнотой и мощностью, что позволяет считать При- 
каспийскую впадину структурой древнего заложения [8].

Новейший этап тектонического развития протекал в Нижнем Поволжье достаточно интенсивно. Суммарная амплитуда тектонических движений за неоген-четвертичное время достигает 1100 м. Это исключает возможность рассматривать древнюю Русскую платформу в качестве малоподвижного, а тем более стабильно тектонического элемента [15]. Для Саратовско-Волгоградского правобережья характерно наличие множества локальных тектонических структур линейного северо-западного простирания, имеющих амплитуды порядка 200-300 м. Их формирование предположительно связано с погружением западной части Прикаспийской низменности [10]. Активные неотектонические движения предопределили образование вдоль линии Волгоградских разломов молодых дизъюнктивных дислокаций - сбросов амплитудой около 200 м. Частью этой системы разрывных нарушений является и хорошо изученный Большой Волгоградский сброс, проходящий непосредственно под сооружениями плотины Волгоградской ГЭС [7].

Рассматриваемый нами Александровский грабен тоже является частью этой системы нарушений. Он расположен в Дубовском районе Волгоградской области, в окрестностях станицы Суводской (в прошлом Александровской). Грабен открыт и описан А.П. Павловым в конце XIX века, хорошо выражен в рельефе, сбрасыватели грабена доступны наблюдению в хорошо обнаженных разрезах $[1,14]$. В период проектирования ГЭС все известные сбросы Нижнего Поволжья тщательно изучались на предмет современной активности, ведь, как было указано выше, один из сбросов проходит под сооружениями Волгоградской ГЭС. Особенно детально изучался Александровский грабен, как наиболее хорошо выраженная в рельефе и геологических разрезах структура. Исследователи констатировали пассивность грабена в послехвалынское время [4, 9].

Материалы и методы исследований. В 2000-х годах в ходе полевых исследований береговой зоны Волгоградского водохранилища нами выявлены геоморфологические признаки современных восходящих тектоничес- ких движений [12]. Предположительно, активизация грабена связана с наполнением чаши Волгоградского водохранилища. Осенью 2009 года в районе грабена заложено 3 поперечных профиля, пересекающих грабен в целом и отдельные сбрасыватели. Глубина и способ закладки реперов исключают влияние сезонных почвенных процессов на высотное положение пунктов геодезической основы.

В 2016-2017 гг., наряду с продолжением изучения геоморфологических признаков тектонических движений [13], проведена повторная нивелировка по трем поперечным створам в южной части грабена (см. рис. 1) и выполнена увязка групп реперов этого створа методами маршрутного нивелирования III класса (в соответствии с «Инструкцией маршрутного нивелирования I, II, III и IV классов») с использованием оптических нивелиров Sokkia 410. Для первого года работ выбран самый южный из профилей, заложенный непосредственно над обнажением, вскрывающим линию восточного сброса грабена (см. рис. 2). Это наиболее показательный участок района работ, на котором отлично видна связь рельефа и геологической структуры. Так же очевидна и связь заложенных реперов с элементами геологической структуры.

Результаты и обсуждение. Результаты двойного нивелирного хода соответствуют III классу. Длина секции составляет 0,35 км. При предельно допустимой погрешности нивелирного хода $8,3 \mathrm{~mm}(\Delta \mathrm{h}=10 \sqrt{\mathrm{L}})$, величина фактической ошибки составила 2,2 мм. На рисунке 3 отражены результаты повторного нивелирования. Главным результатом работ стало установление факта современных движений по линии сброса. За прошедшие с момента закладки полигона и первичной нивелировки 7 лет эти движения проявились и достоверно диагностируются стандартными геодезическими методами. На приведенной схеме показана разница превышений между грунтовыми реперами полигона в 2009 и 2016 гг. Между реперами, находящимися в однородных условиях (западнее линии сброса) разница в превышениях не зафиксирована. Но при сравнении превышений по нивелирным ходам, непосредственно пересекающим линию сброса (напомним, что ее положение здесь можно установить визуально с точностью до 2-3 м) 
Современная тектоническая активность Александровского грабена (Нижнее Поволжье)

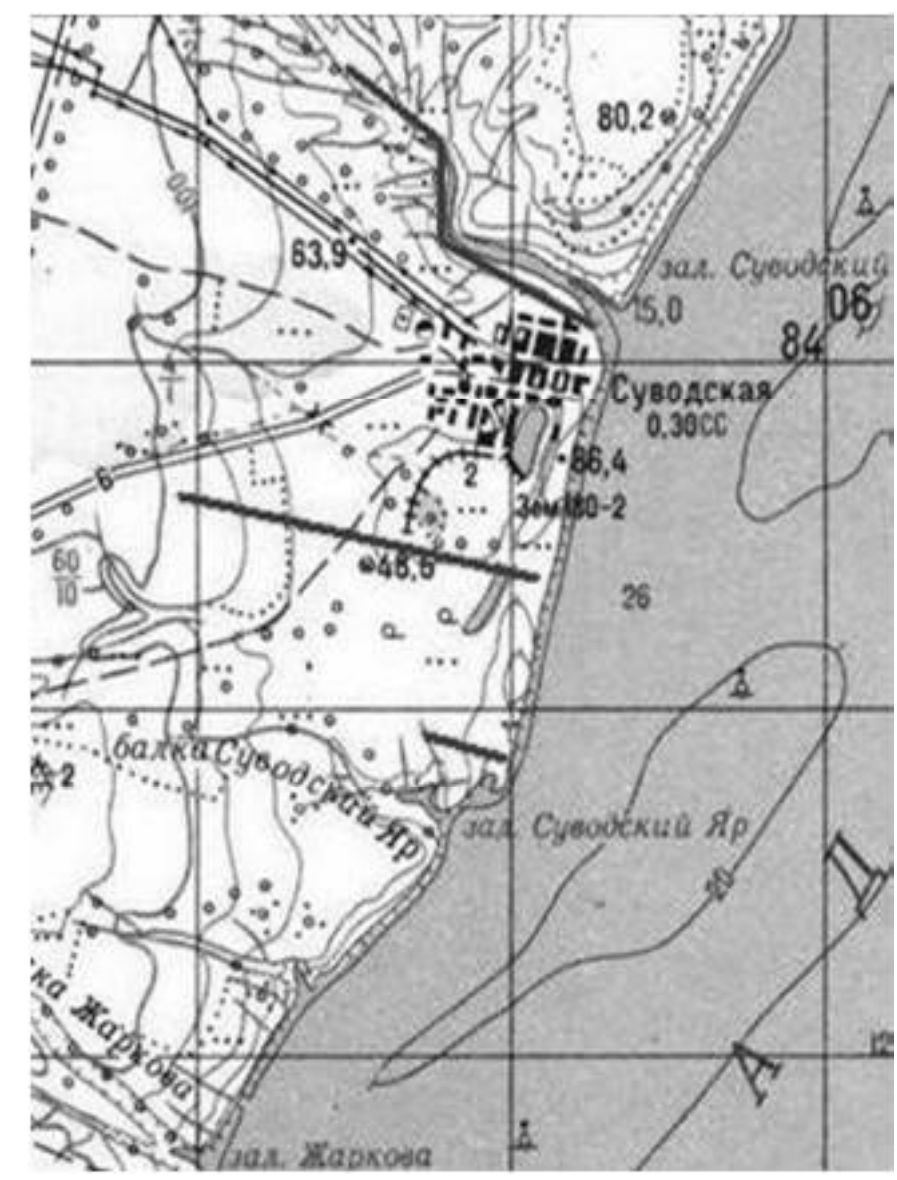

Рис. 1. Схема расположения профилей повторного нивелирования (отмечены жирными черными линиями) в районе Александровского грабена

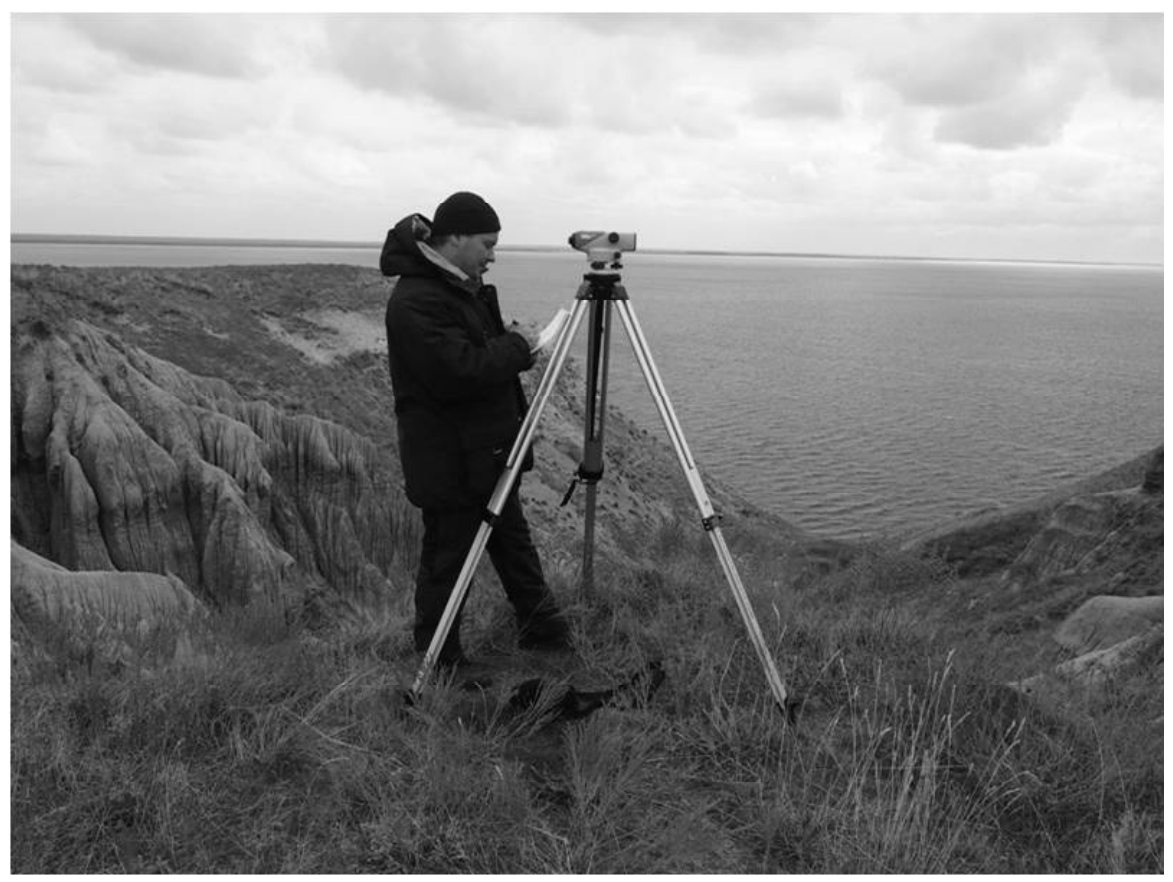

Рис. 2. Повторное нивелирование профиля на южном окончании Александровского грабена, октябрь 2017 г. 


\section{ГЕОГРАФИЯ И ГЕОИНФОРМАТИКА}

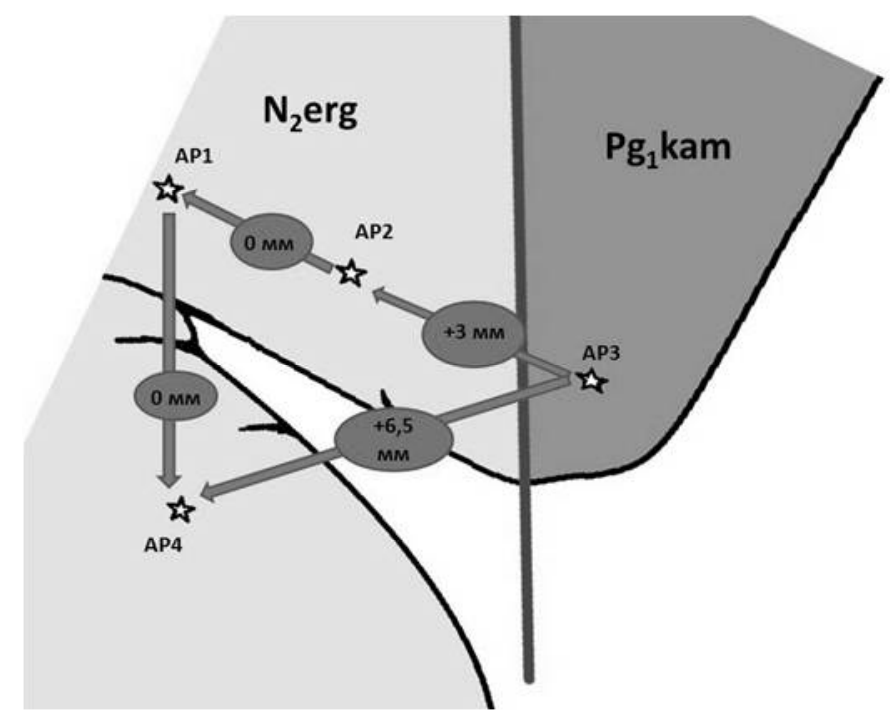

Рис. 3. Результаты повторного нивелирования профиля на южном окончании Александровского грабена:

$\mathrm{Pg}_{1} \mathrm{sar}$ - палеогеновая система, камышинские слои; $\mathrm{N}_{2} \mathrm{erg}$ - неогеновая система, ергенинская свита; AP1, AP2, AP3, AP4 - грунтовые репера; вертикальной линией показано положение восточного сброса

Александровского грабена, стрелками - направления проложения нивелирных ходов

отчетливо видна разница показаний. Полученные данные говорят о поднятии участка, находящегося западнее линии сброса (то есть, собственно зоны грабена). В случае с группой реперов АР $\rightarrow$ AP4 разница составила 6,5 мм. Это дает скорость вертикального смещения поверхности почти 1 мм в год. По общепринятым представлениям, это предельная для платформенных участков скорость, такая подвижность на платформах наблюдается только в ядрах самых активных солянокупольных структур, например, Баскунчакской. Движения четко локализованы и ограничены зоной грабена. Интересно, что в этой зоне движения сменили знак (погружение, создавшее грабен, сменилось подъемом).

В октябре 2017 г. проведено повторное нивелирование всех трех профилей. Работы на южном профиле (профиль № 1) не установили достоверных отличий от результатов, полученных годом ранее, в 2016 г. Самый северный из трех профилей (№ 3 ) показал недостоверные различия с нивелировкой 2009 г. в пределах погрешности измерений.

Наиболее интересные результаты получены при повторном нивелировании профиля № 2 (рис. 4). Профилируемая часть поперечного створа закреплена в узловых точках группами грунтовых реперов, каждая из которых включает по два репера: основной (потайной) и контрольный (открытый). Глубина и способ закладки реперов исключают влияние сезонных почвенных процессов на высотное положение пунктов геодезической основы. Всего установлено шесть групп реперов, которые приурочены к следующим элементам поперечного створа:

Группа № 1: участок территории к востоку от восточного сброса грабена; северный склон гребня «Южный Царь»; репер № 10 основной; репер № 11 - контрольный.

Группа № 2: участок территории, примыкающий к восточному сбросу грабена с западной стороны (западный берег пруда), в 0,38 км к западу от группы № 1; репер № 20 - основной; репер № 21 - контрольный.

Группа № 3: восточная часть центральной котловины грабена (восточная окраина старого сада станицы Суводской), в 0,53 км к западу от группы № 2; репер № 30 - основной; репер № 31 - контрольный.

Группа № 4: средняя продольная ось грабена (центральная часть старого сада станицы Суводской), в 0,29 км к западу от группы № 3; репер № 40 - основной; репер № 41 контрольный.

Группа № 5: западная часть центральной котловины в зоне западного сброса грабена (западная окраина старого сада станицы Суводской), в 0,44 км к западу от группы № 4; репер № 50 - основной; репер № 51 контрольный. 


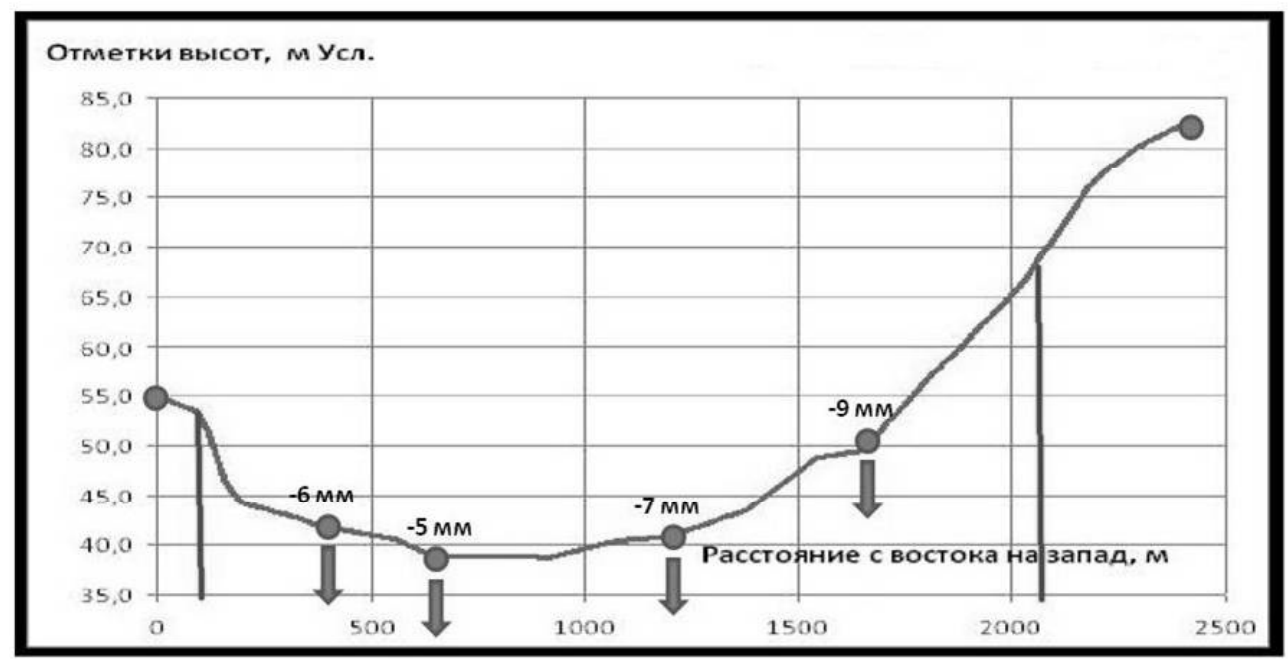

Рис. 4. Направление и величина вертикальных смещений контрольных групп реперов профиля № 2: Вертикальные линии - положение сбрасывателей грабена

Группа № 6: западный гребень тектонической долины (склон гребня к западу от западного сброса грабена), в 0,54 км к западу от группы № 5; репер № 60 - основной; репер № 61 - контрольный.

Методические особенности нивелирования: прямой и обратный ход в исполнении двух бригад нивелировщиков; определение длин линий по дальномеру с постоянным базовым углом; предельная величина неравенства плеч - 5,0 м; предельная погрешность нивелирования на маршруте $\Delta \mathrm{h}, \mathrm{Mm}=20 \sqrt{\mathrm{L}}$, где L, км - длина секции или маршрута нивелирования. Фактическая невязка двойного хода составила 30,0 мм при допустимой невязке 43,6 мм. Результаты двойного нивелирного хода соответствуют III классу.

Заключение. По всем контрольным группам реперов, находящихся в зоне грабена отмечено достоверное нисходящее вертикальное смещение. Величина его колеблется от 5 до 9 мм за 8 лет, прошедшие с момента закладки и первичной увязки пунктов геодезической основы. Это дает среднюю скорость вертикального смещения 0,6-1,1 мм/год, скорость движения возрастает, в целом, с востока на запад (рис. 4). Эта величина сопоставима с вертикальными смещениями ряда реперов профиля № 1, но имеет противоположный знак - на профиле № 1 реперные группы, находящиеся в зоне грабена испытывают восходящее движение. Полученные результаты указывают на наличие сложных и разнонап- равленных современных движений на ограниченном участке Александровского грабена (профили № 1 и 2 находятся на расстоянии всего 1,8 км друг от друга). Севернее темпы современных движений снижаются, так как они выражены геоморфологически, но не выявляются достоверно геодезическими методами. Здесь геоморфологические признаки говорят о восходящих современных движениях.

\section{ПРИМЕЧАНИЕ}

${ }^{1}$ Работа выполнена при финансовой поддержке Российского фонда фундаментальных исследований и Администрации Волгоградской области (проект № 16-45-340801-a).

\section{СПИСОК ЛИТЕРАТУРЫ}

1. Брылев, В. А. Уникальные дизьюнктивные структуры на Юго-востоке Русской равнины и их геоморфологическая выраженность / В. А. Брылев // Теория и методы современной геоморфологии: Материалы XXXV Пленума Геоморфологической комиссии РАН. - Симферополь, 2016. - С. 17-19.

2. Габриэлян, А. Г. Тектоническое районирование Волгоградской области / А. Г. Габриэлян, Е. А. Граблин, Л. Н. Розанов, Ю. А. Салов // Материалы по тектонике Нижнего Поволжья. - Л., 1962. C. 38-48.

3. Гарецкий, Р. Г. Эколого-тектонофизическая среда Беларуси / Р. Г. Гарецкий, Г. И. Каратаев. Минск : Беларуская навука, 2015. - 175 с. 
4. Горелов, С. К. К вопросу о новейшей тектонической активности Александровского грабена / С. К. Горелов, 3. П. Губонина // Вопросы палеогеографии и геоморфологии бассейнов Волги и Урала. -М., 1962.-С. 135-143.

5. Копп, М. Л. Мобилистическая тектоника платформ Юго-Восточной Европы / М. Л. Копп. М. : Наука, 2004. - 340 с.

6. Кайнозойские напряжения востока Русской плиты, Южного и среднего Урала / М. Л. Копп, В. Е. Вержбицкий, А. А. Колесниченко, Т. Ю. Тверитинова, Н. Ю. Васильев, В. А. Корчемагин, Н. В. Макарова, А. О. Мострюков, А. И. Иоффе. M. : ГЕОС, 2014. $-88 \mathrm{c}$.

7. Маменко, Г. К. Плотина Волжской ГЭС им. ХХІІ съезда КПСС на р. Волге / Г. К. Маменко // Геология и плотины. - М., 1972. - T. VI. - С. 54-79.

8. Мещеряков, Ю. А. Геоморфологические данные о новейших тектонических движениях в Прикаспийской низменности / Ю. А. Мещеряков, М. П. Брицына // Геоморфологические исследования в Прикаспийской низменности. - М., 1954. - С. 5-46.

9. Мещеряков, Ю. А. Некоторые геоморфологические особенности районов дизъюнктивных дислокаций Нижнего Поволжья / Ю. А. Мещеряков, Г. В. Обедиентова, М. М. Шукевич // Труды Института географии АН СССР. Материалы по геоморфологии и палеогеографии СССР. - Т. 58. Вып. 10. - М., 1953. - С. 49-69.

10. Наливкин В.Д. Системы разломов востока Русской платформы / В. Д. Наливкин, И. Г. Клушин, И. Н. Толстихин // Материалы по тектонике Нижнего Поволжья. - Л., 1962. - С. 7-18.

11. Новейшая тектоника и геодинамика: область сочленения Восточно-Европейской платформы и Скифской плиты. - М. : Наука, 2006. - 206 с.

12. Солодовников, Д.А. Геологическое строение и современные тектонические движение в районе Александровского грабена / Д. А. Солодовников, О. В. Филиппов // Проблемы комплексного исследования Волгоградского водохранилища. Волгоград : Волгогр. науч. изд-во, 2009. - С. 71-83.

13. Солодовников, Д. А. Геоморфологические методы изучения современных тектонических движений на правобережье Волгоградского водохранилища / Д. А. Солодовников, Н. М. Хаванская, В. Н. Бодрова, Н. В. Вишняков // Вестник Волгоградского государственного университета. Сер. 11. Естественные науки. - 2016. - № 2 (16). - С. 50-56.

14. Шатский, Н.С. Балыклейский грабен и дизъюнктивные дислокации и Южного Поволжья / Н. С. Шатский // Вестник Московской горной академии. - 1922. - Т. 1. - № 1. - С. 15-28.

15. Шафиро, Я. Ш. Тектонические критерии поисков нефти и газа в каменноугольных отложениях северо-запада бортовой зоны Прикаспийской синеклизы / Я. Ш. Шафиро // Геологическое строение и нефтегазоносность юго-востока Восточно-Европейской платформы. - М., 1983. - С. 51-58.

16. Isiaka, A.I. 3D seismic analysis of the AK Fault, Orange Basin, South Africa: Implications for hydrocarbon leakage and offshore neotectonics / A.I. Isiaka, R.J. Durrheim, M.S.D. Manzi, M.A.G. Andreoli // Tectonophysics. - 2017. - 721. - pp. 477-490.

17. Resmi, M. R. Middle to late Holocene paleochannels and migration of the Palar River, Tamil Nadu: Implications of neotectonic activity/M. R. Resmi, H. Achyuthan, M.K. Jaiswal // QuaternaryInternational. 2017. - vol. 443. - pp. 211-222.

18. Santana, J.R.H. Geomorphometric classification of the Mexican relief: A morphographic approach by contour density and relief energy / J.R.H. Santana, J.L.P. Damián, F.R. Vergés, A.P.M. Linares, E.N. Salas // Investigaciones Geograficas. - 2017(94) - pp. 49-63.

19. $\mathrm{Su}, \mathrm{Q}$. Geomorphic features of the Bailongjiang river drainage basin and its relationship with geological disaster. Diqiu Kexue - Zhongguo Dizhi Daxue Xuebao/ Q. Su, M. Liang, D.Yuan, H. Xie, Z. Wu // Earth Science - Journal of China University of Geosciences. - 2016. -41(10). - pp. 1758-1770.

20. Sušić, Z. Present-day Horizontal Mobility in the Serbian Part of the Pannonian Basin; Inferences from the Geometric Analysis ofDeformations/ Z. Sušić, M. Toljić, V. Bulatović, T. Ninkov, U. Stojadinović // Acta Geophysica. -2016. - vol. 64(5). - pp. 1626-1654.

\section{REFERENCES}

1. Brylev V.A. Unikal'nye dizjunktivnye struktury na Jugo-vostoke Russkoj ravniny i ih geomorfologicheskaja vyrazhennost' [Unique disjunctive structures in the South-East of the Russian plain and their geomorphological expression]. Teorija i metody sovremennoj geomorfologii Materialy XXXV Plenuma Geomorfologicheskoj komissii RAN. Simferopol', 2016, pp. 17-19.

2. Gabrijeljan A.G., Grablin E.A., Rozanov L.N., Salov Ju.A. Tektonicheskoe rajonirovanie Volgogradskoj oblasti [Tectonic zoning of the Volgograd region]. Materialy po tektonike Nizhnego Povolzh'ja. Leningrad, 1962, pp. 38-48.

3. Gareckij R.G., Karataev G.I. Jekologotektonofizicheskaja sreda Belarusi [Ecologicalgeodynamic environment of Belarus]. Minsk, Belaruskaja navuka, 2015. 175 p.

4. Gorelov S.K., Gubonina Z.P., K voprosu o novejshej tektonicheskoj aktivnosti Aleksandrovskogo grabena [To the question of recent tectonic activity of the Alexandrovsky graben]. Voprosy paleogeografii i geomorfologii bassejnov Volgi i Urala. Moscow, 1962, pp. 135-143. 
5. Kopp M.L. Mobilisticheskaja tektonika platform Jugo-Vostochnoj Evropy. [Mobilistic neotectonics of platforms of the South-Eastern Europe]. Moscow: Nauka, 2004, 340 p.

6. Kopp M.L., Verzhbickij V.E., KolesnichenkoA.A., Tveritinova T.Ju., Vasil'ev N.Ju., Korchemagin V.A., Makarova N.V., Mostrjukov A.O., Ioffe A.I. Kajnozojskie naprjazhenija vostoka Russkoj plity, Juzhnogo i Srednego Urala [Cenozoic stresses of the East of the Russian plate, southern and middle Urals]. Moscow: GEOS, 2014, 88 p.

7. Mamenko G.K. Plotina Volzhskoj GJeS im. XXII syezda KPSS na r. Volge [Dam of the Volga hydroelectric station. XXII Congress of the CPSU on the river Volga]. Geologija i plotiny. Vol. VI. Moscow, 1972, pp. 54-79.

8. Meshherjakov Ju.A., Bricyna M.P. Geomorfologicheskie dannye o novejshih tektonicheskih dvizhenijah v Prikaspijskoj nizmennosti [Geomorphological data on the latest tectonic movements in the Caspian lowland]. Geomorfologicheskie issledovanija v Prikaspijskoj nizmennosti. Moscow, 1954, pp. 5-46.

9. Meshherjakov Ju.A., Obedientova G.V., Shukevich M.M. Nekotorye geomorfologicheskie osobennosti rajonov dizjunktivnyh dislokacij Nizhnego Povolzh'ja [Some geomorphological features of the areas of disjunctive dislocations of the Lower Volga region]. Trudy Instituta geografii AN SSSR. Vol. 58. Materialy po geomorfologii i paleogeografii SSSR. Vol. 10. Moscow, 1953, pp. 49-69.

10. Nalivkin V.D., Klushin I.G., Tolstihin I.N. Sistemy razlomov vostoka Russkoj platform [Fault systems of the East of the Russian platform]. Materialy po tektonike Nizhnego Povolzh'ja. Leningrad, 1962, pp. 7-18.

11. Novejshaja tektonika i geodinamika: oblast' sochlenenija Vostochno-Evropejskoj platformy i Skifskoj plity [The newest tectonics and geodynamics: the area of articulation of the East European platform and Scythian plate]. Moscow: Nauka, 2006, 206 p.

12. Solodovnikov D.A., Filippov O.V. Geologicheskoe stroenie i sovremennye tektonicheskie dvizhenie v rajone Aleksandrovskogo grabena [Geological structure and current tectonic movement in the area of Alexandrovsky graben]. Problemy kompleksnogo issledovanija Volgogradskogo vodohranilishha. Volgograd: Volgogradskoe nauchnoe izdatel'stvo, 2009, pp. 71-83.
13. Solodovnikov D.A., Havanskaja N.M., Bodrova V.N., Vishnjakov N.V. Geomorfologicheskie metody izuchenija sovremennyh tektonicheskih dvizhenij na pravoberezh'e Volgogradskogo vodohranilishha [Methods geomorphological study of modern tectonic movements on the right Bank of the Volgograd reservoir]. Vestnik Volgogradskogo gosudarstvennogo universiteta. Ser. 11. Estestvennye nauki. 2016, № 2 (16), pp. 50-56.

14. Shatskij N.S. Balyklejskij graben i dizjunktivnye dislokacii i Juzhnogo Povolzh'ja [Balikleyskiy Graben and disjunctive dislocations of Southern Volga region]. Vestnik Moskovskoj gornoj akademii, 1922, vol. 1, № 1 .

15. Shafiro Ja.Sh. Tektonicheskie kriterii poiskov nefti i gaza v kamennougol'nyh otlozhenijah severozapada bortovoj zony Prikaspijskoj sineklizy [Searches and Tectonic criteria of oil and gas in the Carboniferous deposits of the North-West side of the zone of pre-Caspian syneclise]. Geologicheskoe stroenie i neftegazonosnost' jugo-vostoka Vostochno-Evropejskoj platformy. Moscow, 1983, pp. 51-58.

16. Isiaka, A.I., Durrheim, R.J., Manzi, M.S.D., Andreoli, M.A.G. 3D seismic analysis of the AK Fault, Orange Basin, South Africa: Implications for hydrocarbon leakage and offshore neotectonics, Tectonophysics, 2017, 721,pp. 477-490.

17. Resmi, M.R., Achyuthan, H., Jaiswal, M.K. Middle to late Holocene paleochannels and migration of the Palar River, Tamil Nadu, Implications of neotectonic activity. Quaternary International, 2017, 443, pp. 211-222.

18. Santana, J.R.H., Damián, J.L.P., Vergés, F.R., Linares, A.P.M., Salas, E.N. Geomorphometric classification of the Mexican relief: A morphographic approach by contour density and relief energy, Investigaciones Geograficas. 2017(94), pp. 49-63.

19. Su, Q., Liang, M., Yuan, D., Xie, H., Wu, Z. Geomorphic features of the Bailongjiang river drainage basin and its relationship with geological disaster. Diqiu Kexue - Zhongguo Dizhi Daxue Xuebao, Earth Science - Journal of China University of Geosciences, 2016, 41(10), pp. 1758-1770.

20. Sušić, Z., Toljić, M., Bulatović, V., Ninkov, T., Stojadinović, U. Present-day Horizontal Mobility in the Serbian Part of the Pannonian Basin; Inferences from the Geometric Analysis of Deformations, Acta Geophysica, 2016, 64(5), pp. 1626-1654. 


\section{Information about the Authors}

Denis A. Solodovnikov, Candidate of Geographical Sciences, Head of Department of Geography and Cartography, Volgograd State University, Prospekt Universitetskij, 100, 400062 Volgograd, Russian Federation, densolodovnikov@gmail.com,solodovnikov@volsu.ru.

Natalya M. Khavanskaya, Candidate of Geographical Sciences, Associate Professor, Department of Geography and Cartography, Volgograd State University, Prospekt Universitetskij, 100, 400062 Volgograd, Russian Federation, havanskayanm@mail.ru.

Nikolay V. Vishnyakov, Assistant Professor, Department of Geography and Cartography, Volgograd State University, Prospekt Universitetskij, 100, 400062 Volgograd, Russian Federation, nivishnyakov@yandex.ru.

Stanislav S. Shinkarenko, Candidate of Agricultural Sciences, Researcher in FSC of agroecology RAS, Prospekt Universitetskij, 97, 400062 Volgograd, Russian Federation; Associate Professor of Department of Geography and Cartography, Volgograd State University, Prospekt Universitetskij, 100, 400062 Volgograd, Russian Federation, vnialmi@bk.ru.

\section{Информация об авторах}

Денис Анатольевич Солодовников, кандидат географических наук, заведующий кафедрой географии и картографии, Волгоградский государственный университет, просп. Университетский, 100, 400062 г. Волгоград, Российская Федерация, densolodovnikov@gmail.com, solodovnikov@volsu.ru.

Наталья Михайловна Хаванская, кандидат географических наук, доцент кафедры географии и картографии, Волгоградский государственный университет, просп. Университетский, 100, 400062 г. Волгоград, Российская Федерация, havanskayanm@mail.ru.

Николай Владимирович Вишняков, старший преподаватель кафедры географии и картографии, Волгоградский государственный университет, просп. Университетский, 100, 400062 г. Волгоград, Российская Федерация, nivishnyakov@yandex.ru.

Станислав Сергеевич Шинкаренко, кандидат сельскохозяйственных наук, научный сотрудник Федерального научного центра агроэкологии, комплексных мелиораций и защитного лесоразведения Российской академии наук, просп. Университетский, 97, 400062 г. Волгоград, Российская Федерация; доцент кафедры географии и картографии, Волгоградский государственный университет, просп. Университетский, 100, 400062 г. Волгоград, Российская Федерация, vnialmi@bk.ru. 